\title{
Tomasz GrafF
}

\section{DZIALALNOŚĆ POLITYCZNA ZBIGNIEWA OLEŚNICKIEGO I POLSKIEJ HIERARCHII KOŚCIELNEJ W DOBIE TZW. BURZY KORONACYJNEJ}

Postawa Zbigniew Oleśnickiego i najważniejszych hierarchów polskiego episkopatu wobec wydarzeń związanych $\mathrm{z}$ tzw. burzą koronacyjną zasługuje na szczególną uwagę. Biskupi monarchii jagiellońskiej, podobnie jak to miało miejsce w całej chrześcijańskiej Europie, byli wszak najważniejszymi doradcami króla i stale uczestniczyli w kreowaniu polityki państwa ${ }^{1}$. Poniżej postaramy się odpo-

\footnotetext{
${ }^{1} \mathrm{~W}$ tym miejscu warto dodać kilka uwag dotyczących obrazu Zbigniewa Oleśnickiego w Annales Dhugosza. Uważamy, że jest to niezbędne ze względu na poddawaną często w wątpliwość wiarygodność przekazu Długosza o tej postaci - co jest decydujące przy interpretacji Annales - źródła bardzo ważnego dla omawianego przez nas tematu. Nie odrzucamy oczywiście całkowicie tezy, iż Długosz wyolbrzymił nieco rolę biskupa krakowskiego w okresie burzy koronacyjnej, niemniej uważamy, że z pewnością w przebiegu tych wydarzeń jego udział byl znaczący. $Z$ góry odkładamy ad acta szeroko rozpowszechnianą w literaturze opinię, że kronikarz pisząc o Oleśnickim - chcial tylko przysporzyć chwały swojemu protektorowi. Przykładem takiej wizji niech będzie choćby zdanie K. Pieradzkiej, która pisząc o powstaniu Annales, wysnuła tezę o dyktacie Oleśnickiego, który fałszował prawdę historyczną. (K. Pieradzka, Przedmowa do Rozbioru krytycznego ,Annalium Poloniae" Jana Dlugosza z lat 1385-1444, t. 1, pod kierunkiem J. Dąbrowskiego, Wrocław 1961, s. 43; por. M. Bobrzyński, S. S molka, Jan Dlugosz, jego życie i stanowisko w piśmiennictwie, Kraków 1893; I. Zarębski, Gesta Sbignei jako element ewolucji w genezie Annalium Jana Dlugosza, [w:] Prace z dziejów Polski feudalnej ofiarowane Romanowi Grodeckiemu w 70 rocznice urodzin, Warszawa 1960, s. 293-307; M. Koczerska, Dlugosz jako sekretarz Zbigniewa Oleśnickiego, [w:] Jan Dlugosz. W pięćsetnq rocznicé śmierci. Materialy z sesji (Sandomierz 24-25 maja 1980), red. F. Kiryk, Olsztyn 1983, s. 53-63; U. Borkowska, Historiograficzne poglady Jana Dlugosza [w:] Dlugossiana. Studia historyczne w pięćsetlecie śmierci Jana Dtugosza, red. S. Gawęda cz. 2, Warszawa-Kraków 1985, s. 45-71; tejże, Treści ideowe w dziełach Jana Dlugosza, Lublin 1983, s. 23 n.; J. Nikodem, Zbigniew Oleśnicki w dzielach Jana Dlugosza, „Nasza Przeszłość” 87:1997, s. 73-121). Ten sposób rozumowania może doprowadzić do całkowitej falsyfikacji każdego slowa Długosza o biskupie krakowskim. Pamiętać wszak należy, że Oleśnicki rzeczywiście był jednostką ponadprzeciętną, i nie jest to tylko wymysł Długosza, ale mówią o tym fakty znane $\mathrm{z}$ innych źródeł. Oleśnicki był biskupem, który bezsprzecznie wycisnął olbrzymie piętno na dziejach wczesnej monarchii jagiellońskiej $\mathrm{i}$ był zdecydowanie najwybitniejszą jednostką wśród wszystkich hierarchów łacińskich w przeciągu XV wieku. To on jako pierwszy w dziejach polski hierarcha otrzymal kapelusz kardynalski, co tylko świadczy o szacunku jakim się cieszył nie tylko w kraju, ale i zagranicą. Równocześnie przyznajemy, że Długosz niejednokrotnie kosztem Oleśnickiego pomniejszal znaczenie innych osób i przy
} 
wiedzieć na następujące pytanie: jak polscy hierarchowie odnieśli się do możliwości koronacji Witolda w 1429 r. i jaką w związku z tym widzieli przyszłość przed unią polsko-litewską?

Wydarzenia burzy koronacyjnej mają już swoją bogatą literaturę z dziełami A. Prochaski i L. Kolankowskiego na czele ${ }^{2}$. Ostatnio osobną książkę poświecił temu tematowi G. Błaszczyk, godne uwagi są także rozważania J. Nikodema ${ }^{3}$. Postaramy się zatem skupić na najważniejszych elementach owej burzy w stosunkach polsko-litewskich, ze szczególnym uwzględnieniem roli polskich hierarchów.

Propozycja koronacji Witolda stanowiła ogromne zagrożenie dla bytu unii polsko-litewskiej i z punktu widzenia Korony stanowiła również zagrożenie dla niej samej - wobec sojuszu litewsko-luksembursko-krzyżackiego. Rekonstrukcji wydarzeń możemy dokonać nie tylko na podstawie tekstu Długosza, ale i uzupełniających pozostałych źródeł.

Zjazd w Łucku z pewnością był ważnym wydarzeniem w późnośredniowiecznej historii Europy. Spotkali się tam w 1429 r. król rzymski, Czech i Węgier Zygmunt Luksemburski, król Polski i najwyższy książe Litwy Władysław Jagiełło oraz wielki książę litewski Witold Kiejstutowicz. Wiadomo, że w czasie wjazdu trzech władców do Łucka otaczali ich liczni prałaci. Długosz nie omieszkał wymieć swojego pryncypała Zbigniewa Oleśnickiego, który konno towarzyszył przy powitaniu Zygmunta i Witolda. Z kolei w uroczystej procesji naprzeciw władcom wyszedł biskup hucki Andrzej wraz z miejscowym ordynariuszem prawosławnym i przełożonym synagogi. Król rzymski uszanował tylko biskupa katolickiego. Długosz, osobiście nie pałający wielką miłością do innych wyznań, z wielką satysfakcją przy tej okazji pochwalil zachowanie Zygmunta ${ }^{4}$.

W czasie spotkania łuckiego nie zajmowano się jednak sprawami międzywyznaniowymi. Wszystkich Polaków poraziła wszak zaskakująca propozycja króla rzymskiego, który chciał za zgodą Jagiełły doprowadzić do koronacji Witolda. Po zagadkowej akceptacji przez polskiego monarchę tej propozycji, rozpętała się polsko-litewska wojna nerwów. Głos w Łucku zabrali członkowie rady królewskiej.

okazji oczywiście wiele spraw przemilczał, a inne relacje ubarwiał. Tym niemniej, nie podważa to całkowicie wartości jego przekazu o wydarzeniach, w których uczestniczył Oleśnicki.

"A. Prochaska, Zjazd monarchów w Eucku, „Przewodnik Naukowy i Literacki” R. II:1874, t. 1, s. 187-201, 270-288, 376-389, 451-456; t. 2, s. 57-74; tegoż, Ostatnie lata Witolda. Studyum z dziejów intrygi dyplomatycznej, Warszawa 1882; tegoż, Dzieje Witolda w. Księcia Litwy, Wilno 1914; tegoż, Znacznie niedoszlej koronacji Witotda, „Ateneum Wileńskie” R. I:1923, s, 337-351; L. Kolankowski, Dzieje Wielkiego Księstwa Litewskiego za Jagiellonów 1377-1499, t. 1, Warszawa 1930, s. 152 n.; tegoż, O litewska koronę, „Kwartalnik Historyczny” R. 40:1926, s. 386-399; tegoż, Kwestia litewskiej korony, „Ateneum Wileńskie" R. V:1928, z. 15, s. 186-187.

${ }^{3}$ G. Błaszczyk, Burza koronacyjna. Polska - Litwa 1429-1430, Poznań 1998, s. 5 n. - tu zestawiona najważniejsza literatura przedmiotu; J. Nikodem, Spory o koronację księcia Litwy Witolda w latach 1429 -1430 , cz. I: Burza koronacyjna w relacji Jana Dlugosza, „Lituano-Slavica Posnaniensia. Studia Historica” VI:1994 [wyd. 1995], s. 55-75 i cz. II: Próba rekonstrukcji wydarzeń, „Lituano-Slavica Posnaniensia. Studia Historica" VII:1995 [wyd. 1997], s. 155-171.

${ }^{4}$ Ioannis Dlugossii Annales seu cronicae incliti Regni Poloniae[Dalej:Annales], lib. XI:1413-1430, ed. C. Baczkowski et al., Varsaviae 2000, s. 247-248. 
Długosz stwierdził, że prymas Wojciech Jastrzębiec mówił długo i pięknie, ale nie można było wyczytać z tej mowy, jakie jest jego zdanie (verbis longis factis nihil certi aut disseruit aut determinavit, sed rem in ambiguo reliquit) ${ }^{5}$. Tutaj rzeczywiście możemy podejrzewać Długosza, że dla kontrastu z Oleśnickim ukazał nijaką postawę prymasa, ale $\mathrm{z}$ drugiej strony, czy możliwe jest wykazanie, że relacja ta jest nieprawdziwa? Może Jastrzębiec doszedł do wniosku, że wszystko trzeba sobie starannie przemyśleć, wybadać nastroje i dopiero potem zająć wyraźne stanowisko? A może propozycja koronacji tak ,zaćmiła” chwilowo jego umysł, że nie był w stanie nic sensownego powiedzieć i nie zauważył niebezpieczeństwa, jakie przyszła koronacja może sprowadzić na Polskę? Tego nie wiemy i nigdy się nie dowiemy. Wydaje się jednak, że gdyby prymas od początku ostro zaprotestował przeciw tej propozycji, to Długosz mimo wszystko poświęciłby temu kilka słów. Jeśli zaś idzie o protest Oleśnickiego, to $\mathrm{z}$ pewnością, choć ludzie tej epoki lubowali się w emocjonalnych gestach, nie musiał być on w rzeczywistości aż tak gwałtowny i teatralny. Niemniej ogólny ton wypowiedzi biskupa nie został raczej przez kronikarza zafałszowany. G. Lichończak-Nurek broniła Jastrzębca, twierdząc, że jego postawa wynikała $\mathrm{z}$ bariery psychologicznej, jaka wytworzyła się dzięki dobrym stosunkom z Witołdem, gdyż był uważany za jego człowieka. Innym powodem miało być antykoronacyjne stanowisko Oleśnickiego i Szafrańców, którzy nie byli mu przyjaźni. Ponadto $\mathrm{w}$ opinii Lichończak ostrożność prymasa nie powinna dziwić, wszak zgodę na koronację miał wyrazić sam król, a zatem Jastrzębiec postąpił jak prawdziwy dyplomata ${ }^{6}$. Naszym zdaniem, zakładając oczywiście prawdziwość relacji Długosza, nie należy tchórzostwa nazywać dyplomacją, tym bardziej, że sama autorka przyznaje, że projekt wywyższenia Witolda, równał się faktycznemu zerwaniu unii. Nie są to więc argumenty zasługujące na uznanie. Według Długosza biskup krakowski wyraźnie powoływał się na unię krewską i przyrzeczenie inkorporacji Litwy (si terre Lithuanie fidem catholicam susciperent et perpetuo una cum terris Russie Regno Polonie et unirentur et subiicerentur), co nie dziwi, gdyż w kryzysowych momentach argument inkorporacyjny mógł być istotnym straszakiem dla burzących się Litwinów. Oczywiście, w praktyce nie oznaczało to, że dostojnicy wysuwający argumenty inkorporacyjne nie akceptowali faktycznie rzeczywistego stanu, który równał się znacznej emancypacji i samodzielności Litwy. Zapisów inkorporacyjnych po prostu nie można było wtedy wprowadzić w życie. Oleśnicki powołał się również na inne umowy i zobowiązania ze szczególnym uwzględnieniem unii horodelskiej, wyraźnie zaznaczając, że te dokumenty przecież nie wyparowały, a wręcz przeciwnie - wszak ciągle istnieją z podpisami m.in. Witolda i innych dostojników litewskich. Biskup przypomniał, że uczestnictwo w szlachectwie i znakach herbowych dokonało się $\mathrm{z}$ inspiracji samego króla Zyg-

\footnotetext{
${ }^{5}$ Tamże, s. 250-253.

${ }^{6}$ G. Lichończak-Nurek, Wojciech herbu Jastrzębiec. Arcybiskup i mq̨ż stanu (ok. 1362--1436), Kraków 1996 , s. $165-167$.
} 
munta (ex consilio Sigismundi regis). Dlaczego więc, skoro strona polska zachowuje wszystkie umowy, ba, z pewnością wizja koron królewskich i następstwa dla synów Jagiełłowych jest realna, usiłuje się oderwać od Królestwa ziemie niczym w jednym ciele wieczyście złączone? Nie bez złośliwości biskup zauważył ponadto, że unia miała na celu nie bogactwa Litwy, których wszak jej zawsze brakowało, ani jej potęgę, bo w okresie krewskim Litwa prawie dogorywała, ale jedynym celem było rozszerzenie wiary chrześcijańskiej, co pomogło pokonać wspólnych wrogów - krzyżaków. Następnie Oleśnicki wyraźnie zaznaczył, że nigdy nie opowie się za koronacją i co sił ją będzie zwalczał. I tutaj padają symboliczne słowa najpełniej obrazujące ten 2-letni konflikt - „dawno przeczuwaliśmy, iż ta burza w sposób tak chytry przygotowana spadnie na nasze głowy" (Dudum hanc procellam in tuam et nostram cervicem calido satis ingenio comparatam noscitabamus). Według Oleśnickiego - dziwne jednak jest to, że Witold dał się tak wywieść w pole przez Zygmunta, będąc zaślepionym żądzą znikomej chwały. Tak postępując skaża miłość braterską, dzięki której osiągnął lepszą pozycję nad innymi braćmi królewskimi. Tutaj Oleśnicki wtrącił jednak ukryte ostrzeżenie - wszak nie bezwarunkowo. Można przypuszczać, że stanowisko biskupa poparł nie tylko wymieniony przez biskupa Jan-Tarnowski, ale bezimienni pozostali polscy panowie - duchowni i świeccy ${ }^{7}$. Wiemy, że obecnym na zjeździe łuckim był z pewnością również biskup poznański Stanisław Ciołek ${ }^{8}$. Zachował się m.in. list króla nakazujący wstrzymanie wszelkich spraw sądowych biskupa poznańskiego i jego diecezji w związku ze zjazdem w Łucku?.

Wydaje się, że sprzeciw wobec koronacji był zdrowym odruchem w imię racji stanu Królestwa Polskiego, który nie był obcy tylko Oleśnickiemu, ale i pozostałym prałatom polskim, nawet $z$ enigmatycznym Jastrzębcem na czele. Zresżą działania polskich dostojników kronikarz przedstawia jako spójny sprzeciw, zakończony symbolicznym i manifestacyjnym wyjazdem z Łucka (przy okazji panowie powiedzieli królowi m.in.: Consurgere vides nubem trucis et cruenti belli, procellam tonantem aspicis magno cruoris imbre, nisi aliquid interea Divino numine per nos pro eius resolucione prospectum fuerit, na co król ad hec lacrimis obortis gracias fidei eorum agit, negat se unquam in coronocaionem ducis Withaudi consensisse, offert se velle discedere et ire quocunque consignarent. Ita prelati et barones Regni Polonie quasi grege facto e Luczsko evolant, a król opuścił Łuck następnej nocy, obawiając się gniewu swoich dostojników $)^{10}$. Następnie miały miejsce działania dyplomatyczne wszystkich zainteresowanych stron. Dodajmy, że tuż po zjeź-

\footnotetext{
${ }^{7}$ Annales, XI, s. 253-255.

"Codex epistolaris Vitoldi Magni Ducis Lithuaniae 1376-1430, ed. A. Prochaska, Cracoviae 1882 [dalej: Cod. Vit.], nr 1337; Z. Kowalska, Stanisław Ciolek (zm. 1437). Podkanclerzy królewski, biskup poznański, poeta dworski, Kraków 1993, s. 119.

${ }^{9}$ Kodeks Dyplomatyczny Wielkopolski, t. DX, wyd. A. Gąsiorowski, T. Jasiński, Warszawa-Poznań 1990, nr 1197 (w Brześciu Kujawskim 15 kwietnia 1429 r.).

${ }^{10}$ Annales, XI, s. 255-256.
} 
dzie łuckim, król spotkał się z członkami swojej rady w Sandomierzu (23 lutego) tutaj widzimy oprócz przyszłego biskupa włocławskiego Władysława Oporowskiego, a także: prymasa Jastrzębca, biskupa Oleśnickiego, kanclerza i biskupa włocławskiego Jana Szafrańca ${ }^{11}$. Spotkania $z$ najbliższymi doradcami-biskupami (m.in. $z$ biskupem chełmskim Janem Biskupcem) i panami świeckimi na tle sporu koronacyjnego, były bardzo częste także w następnych dniach, tygodniach i miesiącach ${ }^{12}$. Co symboliczne, w każdym z 3 poselstw do wielkiego księcia Witolda uczestniczył biskup krakowski Zbigniew Oleśnicki. Grożono Witoldowi zbrojną konfrontacją, świecono przed oczami polską koroną (zgoda na koronację Witolda kosztem Jagiełły ${ }^{13}$, była udzielona niewątpliwie przez najważniejszych członków rady królewskiej. Po śmierci Witolda koronę miał zaś otrzymać jeden z synów Jagiełły) i przy okazji powtarzano całą standardową argumentację strony polskiej. Dodajmy, że Witold w tym samym czasie oburzył się na dokument jedlneński, który regulował kwestie dziedziczenia po śmierci Jagiełły i w związku z tym jeszcze 15 marca 1430 r. doniósł wielkiemu mistrzowi krzyżackiemu, iż ma zamiar podjąć konkretne działania przeciw tym zapisom ${ }^{14}$. W każdym razie rokowania polsko-litewskie skończyły się fiaskiem, a korona nie dotarła ostatecznie do wielkiego księcia ${ }^{15}$. Witold usiłował w tym czasie nawet przekupić biskupa krakowskiego, postrzeganego jako najmocniejsze ogniwo reprezentacji polskiej. $Z$ kolei kiedy po przechwyceniu poselstwa od króla rzymskiego $z$ listami demaskującymi konszachty luksembursko-litewsko-krzyżackie, Witold niespodziewanie zaprosił króla do Wilna - panowie polscy postanowili, aby Oleśnicki odegrał kolejną ważną rolę. Otóż uradzono, że królowi ma towarzyszyć właśnie biskup krakowski, aby w razie czego miał oko na władcę, który może dać się omamić Witoldowi. Kuzyn królewski wszak nadal uparcie dążył do celu i przyznać mu trzeba, iż jego argument, że koronacja już jest rozgłoszona po świecie i dyshonorem byłoby ją odwoływać, nie był pozbawiony

${ }^{11}$ Zbiór dokumentów malopolskich, wyd. S. Kuraś, I. Sułkowska-Kurasiowa, cz. VII, Kraków-Wroclaw 1975, nr 2032.

${ }^{12}$ Np. Annales, XI, s. 255 n.; Zbiór dokumentów malopolskich, cz. VII, nr 2033, 2050; cz. II, nr 2036 -2037; Starodawne Prawa Polskiego Pomniki, t. II, wyd.. A. Z. Helcel, Kraków 1870, s. 335; Cod. Vit., nr 1364; Kodeks Dyplomatyczny Matopolski, t. 4, wyd. F. Piekosiński, Kraków 1905, nr 1263-1265, 1275; Codex diplomaticus ecclesiae cathedralis necnon diocesis Vilnensis, t. I, ed. J. Fijałek, W. Semkowicz [Dalej: Cod. Cath. Vil.], Cracoviae 1932-1948, nr 110. Zob. też: A. Gąsiorowski, Itinerarium króla Wladystawa Jagielty 1386-1434, Warszawa 1972, s. 87-89; J. Sperka, Szafrańcowie herbu Stary Koń. Z dziejów kariery $i$ awansu w późnośredniowiecznej Polsce, Katowice 2001, Aneks 2.

${ }^{13}$ Zob. m.in. w tej sprawie list Witolda relacjonujący poselstwo biskupa Oleśnickiego i Jana Tarnowskiego - Cod. Vit., nr 1383 ( 3 X 1429). J. Sperka, Szafrańcowie, s. 196 pomysł dożywotniej korony dla Witolda widział m.in. w inspiracji Szafrańcow, jednak niestety nie da się tego jednoznacznie stwierdzić, podobnie jak wysnutego przez Sperkę (tamże, przyp. 779) przypuszczenia, że obecny był tam również arcybiskup Wojciech Jastrzębiec. Niemniej w zjeździe w Lublinie (IX 1430), który zajmował się tą sprawą, brał z pewnością udział Jan Szafraniec, jak również Jan Biskupiec ordynariusz chełmski - por. Cod. Vit., nr 1453, 1456; Zbiór dokumentów malopolskich, cz. VII, nr 2050.

${ }^{14}$ Cod. Vit., nr 1402.

${ }^{15}$ Zob. K. Górska-Gołaska, Zasadzka rycerstwa wielkopolskiego na drodze margrabińskiej pod Turza Górą I430 r., „Studia i Materiały do Dziejów Wielkopolski i Pomorza” t. 23:1976, s. 53-62. 
racji. W czasie tego poselstwa Oleśnicki na uładzone słowa wielkiego mistrza krzyżackiego Pawła Russdorfa, wypalił krzyżakowi prosto w twarz, że jego piękne słowa nijak mają się do listów, które właśnie przechwycono i które demaskują spisek antypolski w oparciu o koronację Witolda. Podczas tej wizyty Jagiełły na Litwie, monarsze towarzyszyli również inni prałaci, nie wymienieni przez Długosza $\mathrm{z}$ imienia, a biskup wileński Maciej (gorący zwolennik koronacji wielkiego księcia) uzyskał nawet od króla potwierdzenie darowizny dóbr dla kościoła wileńskie$\mathrm{go}^{16}$. Z pewnością Długosz przemilczał rolę, jaką odgrywał w opisywanych wydarzeniach jeden $z$ głównych inspiratorów posunięć strony polskiej, kanclerz i biskup włocławski Jan Szafraniec, który notabene towarzyszył królowi w tej podróży ${ }^{17}$. Sprzeciw Szafrańca był zapewne bardzo wyraźny, zresztą co znamienne, korespondencja Witolda z Zygmuntem Luksemburskim i Jagiełłą, jako głównych przeciwników koronacji wymienia właśnie Jana i Piotra Szafrańców, jak również przyszłego biskupa włocławskiego Władysława Oporowskiego ${ }^{18}$. Niemniej w tym momencie powstaje zasadnicze pytanie - dlaczego Polacy w każdym poselstwie wysyłali na Litwę Zbigniewa Oleśnickiego? Wszak z pewnością nie był on wtedy szczególnie miły Witoldowi, co mogło znacznie utrudnić rozmowy. Otóż wydaje się, że przez osobę Oleśnickiego starano się podkreślić niezłomność sprzeciwu polskiego wobec koronacji. Tę niezłomność, przyznajmy, biskup doskonale symbolizował. Potwierdził to sam Witold, który stwierdził, że o Zbigniewa, niczym o twardą opokę rozbijają się wszelkie jego usiłowania. A było to po próbie przekupienia Zbigniewa, którego przez swoich posłów przekonać chciał za radą króla Witold. Do tych delegatów Witold dołączył także biskupa wileńskiego Macieja. Wielki książę chytrze prosił Oleśnickiego o zgodę na koronację pozorną, co biskup łatwo zbił, że po tym fakcie nikt nie odróżni koronacji rzeczywistej od pozornej. Zabiegi Witolda nie dziwią, gdyż Jagiełło dobitnie stwierdził, że ze względu na wolę polskich dostojników, nic bez Zbigniewa uczynić nie może. Witold oprócz próby przekupstwa posunął się wobec hierarchy nawet do groźby pozbawienia biskupstwa krakowskiego, tak jak to zrobił w przypadku Piotra Wysza. Oleśnicki potępiając ten haniebny postępek miał stwierdzić odważnie, że i czasy i osoby inne, więc jest to niemożliwe, a papież po zażegnaniu schizmy, jest zupełnie inny niż ten, który Wysza usunął z Krakowa ${ }^{19}$. Wypada dodać, że duży wpływ na sporządzone w tym czasie

${ }^{16}$ Annales, XI, s. 293-295; por. Cod. Cath. Vil., nr 110. O sojuszu luksembursko-krzyżacko-litewskim świadczą dokumenty, w których wielki książę Witold zaznaczył, że nic nie zrobi w sporze o koronę bez zgody Zygmunta Luksemburskiego i zakonu: Cod. Vit., nr 1426, 1458; zob. też: tamże, nr 1369 (wielki mistrz do Zygmunta): por. J. Nikodem, Spory o koronacje, z. 2, s. 157 i przyp. 8.

${ }^{17} \mathrm{~Np}$. na wspomnianym wyżej dyplomie dla Kościoła wileńskiego, znajdujemy również w formule datum per manus biskupa włocławskiego Szafrańca i Władysława Oporowskiego. Natomiast J. Nikodem, Spory o koronację, cz. II, s. 171, błędnie twierdził, że dokument ten potwierdza obecność biskupa Oleśnickiego u boku króla.

${ }^{18}$ Cod. Vit., nr 1347, 1352, 1357-1358, 1374, 1392,1480, 1497.

${ }^{19}$ Annales, XI, s. 296-298. Zob. też: T. Graff, Rex iniustus? - Z dziejów polityki kościelnej Wladysława Jagielly na przykladzie zmian na stolicach biskupich w Krakowie i Poznaniu w 1412 roku, [w:] Sprawie- 
opinie prawne profesorów krakowskich (tzw. consilium), negujące w odróżnieniu od prawa papieskiego - prawo Zygmunta Luksemburskiego (wybranego, ale nie koronowanego jeszcze na cesarza) do ofiarowania korony Witoldowi, miał z pewnością ktoś z trójki: Zbigniew Oleśnicki (kanclerz Uniwersytetu), Jan Szafraniec (kanclerz Królestwa) i Władysław Oporowski (podkanclerzy Królestwa) ${ }^{20}$. Co ciekawe, w trwającej w czasie burzy koronacyjnej ofensywie dyplomatycznej wszystkich zainteresowanych stron, sukces osiągnęli głównie Polacy, gdyż ostatecznie papież Marcin V przychylił się do argumentacji strony polskiej, o czy świadczą listy papieskie i jego wysłanników do Zygmunta Luksemburskiego, Witolda i Jagiełły, jak również do innych osób ${ }^{21}$. Słusznie zauważył G. Błaszczyk, że „papież zajął wówczas zdecydowane i jednoznaczne stanowisko po stronie Polski”"22, co oczywiście można traktować jako policzek dla Zygmunta Luksemburskiego ${ }^{23}$. Upadający coraz szybciej na zdrowiu Witold odwołał w końcu w obecności Polaków swoje starania o koronację, a ci z rozkazu Jagiełly zostali odesłani do Polski, co wzbudziło obawy u polskich dostojników. Długosz podał, że w ten sposób Jagiełło chciał mieć wolną rękę w osadzeniu po śmierci Witolda na tronie wielkoksiążęcym Świdrygiełły. W każdym razie Witold nie doczekał już następnego roku, a ostatnie namaszczenie przyjąłz rąk biskupa wileńskiego Macieja 27 X $1430 \mathrm{r.}^{24}$

Wkrótce potem w spontanicznym zajmowaniu zamków na Podolu, jedną z głównych ról odegrał biskup kamieniecki Paweł z Bojańczyc (zwłaszcza przy zajęciu Kamieńca) ${ }^{25}$. Dodajmy, że biskup kamieniecki zajął pierwsze miejsce na liście świadków dokumentu szlachty ziemi podolskiej wystawionego w Kamieńcu

dliwość-Tradycja-Wspólczesność, pod red. P. Nowakowskiego, J. Smołuchy, W. Szymborskiego, Kraków 2006, s. 23-36.

${ }^{20}$ Zob. Codex epistolaris saeculi decimi quinti [Dalej: Cod. ep.], t. 2, ed. A. Lewicki, Cracoviac 1891, nr 179, 185; S. Zachorowski, Studya z historyi prawa kościelnego i polskiego, Kraków 1897, s. 153-166, dod. nr 1, s. 187-192.

${ }_{21}$ Cod. Vit., nr 34 (dodatek - bulla do Zygmunta, aby ten wstrzymał się z wysłaniem korony dla Witolda, mimo jego zasług. Zob. też list legata Andrzeja z Rodos, Cod. Vit., nr 1370, który miał uśmierzyć konflikt). Papież zakazał też biskupowi chełmińskiemu J. Mergenau udziału w koronacji Witolda (Cod. ep., t.2, nr 186, s. 253.); Listy papieża z tego okresu zob. u J. Dhugosza: Annales, XI, s. 257 n., 271-275; zob. też: Bullarium Poloniae, t. 4, ed. et cur. I. Sułkowska-Kuraś et St. Kuraś ac H. Wajs, Romae 1992, nr 2381-2382; por. A. Prochaska, Znaczenie niedoszlej koronacji Witolda, s. 345-346; J. Nikodem, Spory o koronacje, cz. 2 , s. $168-169$.

${ }^{22}$ G. Błaszczyk, Burza koronacyjna, s. 142-147.

${ }^{23} \mathrm{O}$ stosunkach Zygmunta Luksemburskiego z papiestwem zob.: P. Erdö, A Pápaság és a magyar királyság Zsigmond király idején (1387-1437), [w:] Magyarország és A Szentszék Kapcsolatának 1000 éve, red. I. Zombori, Budapest 1996, s. 83-95.

${ }^{24}$ Annales, XI, s. $300-303$.

${ }^{25}$ Tamże, s. 309-311; J. Kurtyka, Podole pomiędzy Polska i Litwa w XIV i 1. polowie XV wieku, [w:] Kamieniec Podolski. Studia z dziejów miasta i regionu, t.1, pod red. F. Kiryka, Kraków 2000, s. 39. W odpowiedzi na akcję zbrojną poddanych króla, Świdrygiełło kategorycznie zażądał zwrotu zabranych zamków por. Cod. Vit., nr 1461. 
23 VI 1439 r., a dotyczącego ponowienia postanowień z 1430 r. w kwestii dziedziczenia tronu przez któregoś z synów Jagiełly ${ }^{26}$.

Wracając jednak do pierwszych miesięcy po śmierci Witolda, warto zauważyć, że w tym okresie wobec uwięzienia króla przez Świdrygiełłę, kancelaria królewska natychmiast interweniowała w Stolicy Apostolskiej. Zapewne mózgiem tej akcji był Jan Szafraniec. Papież w odpowiedzi na polskie wołania żądał od Świdrygiełly, aby ten uwolnił brata, pisał też m.in. do Jagiełły i polskich panów oraz do Zygmunta $^{27}$. Do Świdrygiełły wysłano natomiast delegację z Oleśnickim i Szafrańcem na czele, $\mathrm{z}$ żądaniem uwolnienia monarchy. W tle tej akcji zarządzono mobilizację sił zbrojnych ${ }^{28}$. W okresie konfliktu ze Świdrygiełłą i zakonem zaangażowanie polskich biskupów, było znaczne i mieli oni wpływ na każde ważniejsze posunięcie polityczne w tym okresie. Godna uwagi jest stała obecnośc prominentnych członków episkopatu monarchii Jagiełłowej przy sporządzaniu ważnych dokumentów określających stosunki z Litwą pod rządami Zygmunta Kiejstutowicza:

Oto wykaz najważniejszych aktów, wraz podaniem imion biskupów, którzy byli obecni przy ich wystawianiu:

1. a i b. Dwa dokumenty wystawione w Grodnie przez Zygmunta Kiejstutowicza z 15 października 1432 r. - biskup wileński Maciej i biskup łucki Andrzej ${ }^{29}$.

2. Dokument Władysława Jagiełly z 3 stycznia 1433 r., wydany w Krakowie i nadający Zygmuntowi Kiejstutowiczowi w dożywocie zarząd Wielkiego Księstwa arcybiskup gnieźnieński Wojciech Jastrzębiec, biskup krakowski Zbigniew Oleśnicki, biskup włocławski Jan Szafraniec i biskup chełmski Jan Biskupiec ${ }^{30}$.

3. Dokument Zygmunta Kiejstutowicza wystawiony w Trokach 20 stycznia 1433 r., gdzie przyrzeka wierność królowi i Koronie po otrzymaniu dożywocia - biskup wileński Maciej i biskup łucki Andrzej ${ }^{31}$.

4. Dokument Władysława Jagiełly wydany w Korczynie 27 lutego $1434 \mathrm{r}$. w sprawie nadania dożywocia Zygmuntowi Kiejstutowiczowi oraz w kwestii jego praw i obowiązków - arcybiskup gnieźnieński Wojciech Jastrzębiec, biskup krakowski Zbigniew Oleśnicki, biskup poznański Stanisław Ciołek, biskup chełmski Jan Biskupiec i elekt włocławski Władysław Oporowski ${ }^{32}$.

26 Z. Spieralski, Z Dziejów Archiwum Koronnego Krakowskiego, „Studia Źródłoznawcze” t. 24:1979, s. 133-134; por. J. Kurtyka, Podole, s. 4446.

${ }^{27}$ Annales, XI, s. 313-319; Bullarium Poloniae, t. 4, nr 2531-2534.

${ }^{28}$ Annales, XI, s. 319-321.

${ }_{29}^{29}$ Akta unii Polski z Litwq 1385-1791, wyd. S. Kutrzeba, W. Semkowicz, Kraków 1932, nr 55-56 (drugi dokument dotyczył przynależności Horodła do Korony); por. Annales, XI-XII:1431-1444, ed. C. Baczkowski et al., Varsaviae 2001, s. 71-72.

${ }^{30}$ Akta unii, $\mathrm{nr} 58$.

${ }^{31}$ Tamże, nr 59.

${ }^{32}$ Tamże, nr 60. 
6. Dokument Zygmunta Kiejstutowicza z Grodna wystawiony 27 lutego 1434 r., gdzie przyrzeka wierność królowi i Koronie i jeszcze raz określa swoje obowiązki: biskup wileński Maciej i biskup łucki Andrzej ${ }^{33}$.

7. Dokument Zygmunta Kiejstutowicza z Grodna wystawiony 6 grudnia 1437 r., gdzie ponawia umowy zawarte poprzednio i czyni zastrzeżenia w sprawie ziem, które maja być wydane królowi i Koronie Polskiej: biskup wileński Maciej ${ }^{34}$.

8. Dokument z Grodna wystawiony 6 grudnia 1437 r., gdzie polscy posłowie potwierdzają wcześniejsze umowy z Zygmuntem Kiejstutowiczem i obiecują pomoc przeciw Świdrygielle - arcybiskup gnieźnieński Wincenty Kot i biskup krakowski Zbigniew Oleśnicki ${ }^{35}$.

9. Dokument $\mathrm{z}$ dnia 16 grudnia 1438 r. wystawiony w Piotrkowie po osiągnięciu pełnoletniości przez króla Władysława, w którym przyrzeka, że będzie przestrzegał umów zawartych przez jego ojca z Zygmuntem Kiejstutowiczem - arcybiskup gnieźnieński Wincenty Kot, biskup krakowski Zbigniew Oleśnicki, biskup włocławski Władysław Oporowski i konfirmowany elekt poznański Andrzej z Bnina ${ }^{36}$.

Co interesujące, Świdrygiełło uważał czołowych przedstawicieli polskiego episkopatu za swoịch głównych wrogów, co tylko wzmacnia wymowę w/w dokumentów. Brat Jagiełły $w$ tym kontekście $w$ jednym $z$ listów wymienił: prymasa Wojciecha Jastrzębca, biskupa krakowskiego Zbigniewa Oleśnickiego oraz brata biskupa włocławskiego Piotra Szafrańca ${ }^{37}$. Przeczy to tezie E. Maleczyńskiej, jakoby Szafrańce aprobowali wyniesienie Świdrygiełły, chyba że wobec zaistniałych warunków politycznych bardzo szybko zmienili zdanie ${ }^{38}$.

Dodajmy, że w 1434 r. interweniował w sprawie pogodzenia Świdrygiełly i Zygmunta Kiejstutowicza sam papież Eugeniusz IV. Według Ojca Świętego idealnymi mediatorami w tym sporze powinni być m.in.: biskup wileński Maciej i ordynariusz kamieniecki Paweł z Bojańczyc. Dlatego też obaj dostojnicy otrzymali listy w tej sprawie ${ }^{39} .3$ lata później, w 1437 r., Świdrygiełło porozumiał się z panami ziemi lwowskiej i oddał im Łuck i Olesko ${ }^{40}$. Ponadto postarał się o pogodzenie z młodym królem Władysławem i uznał jego panowanie. To spotkało się z gwałtowną reakcją Oleśnickiego, który opowiedział się po stronie praw Zygmunta Kiejstutowicza. Zapewne w wyniku jego sugestii wysłano ze zjazdu w Sieradzu poselstwo do Zygmunta, które miało na celu polubowne zakończyć jego spór ze

${ }^{33}$ Tamże, nr 61 .

${ }^{34}$ Tamże, nr 63.

${ }^{35}$ Tamże, $\mathrm{nr} 64$.

${ }^{36}$ Tamże, nr 65.

${ }^{37}$ Cod. ep., t.3, ed. A. Lewicki, Cracoviae 1894, dod., nr 10.

${ }^{38}$ E. Maleczyńskiej, Spoleczeństwo polskie pierwszej polowy XV wieku wobec zagadnień zachodnich. Studia nad dynastyczna polityka Jagiellonów, Wroclaw 1947, s. 126.

${ }^{39}$ Cod. Cath. Vil., nr 136; T. Narbutt, Dzieje narodu litewskiego, t. 7, Wilno 1840, dod. s. 62-63.

${ }^{40}$ Cod. ep., t.1, ed. A. Sokołowski, J. Szujski; Cracoviae 1876, nr 91-92; Annales, XI-XII, s. 175; por. A. Lewicki, Powstanie Świdrygielly. Ustęp z dziejów unii Litwy z Korona, Rozprawy (Polskiej) Akademii Umiejętności, Wydział Historyczno-Filozoficzny, t.29:1892, s. 276-279. 
Świdrygiełłą. Oczywiście Oleśnicki zadbał, aby znaleźć się razem z prymasem Wincentym Kotem w składzie polskiej delegacji. Ostatecznie rozmowy te doprowadziły do odmowy ze strony Kiejstutowicza na pogodzenie się ze Świdrygiełłą. Innym efektem było odnowienie unii grodzieńskiej ${ }^{41}$.

Tutaj warto nadmienić, że sprawa Świdrygiełły nie miała szans zwycięstwa właściwie już po podpisaniu w 1435 r. pokoju brzeskiego, czego symbolem była jego ucieczka do Mołdawii w 1438 r. Zdaniem m.in. L. Kolankowskiego i M. Biskupa to wydarzenie było sukcesem inkorporacyjnie nastawionego Oleśnickiego, tym bardziej, ze Albrecht II stracił w Świdrygielle potencjalnego sprzymierzeńca ${ }^{42}$. Jest to tylko częściowa prawda, bo jak wiemy Zygmunt Kiejstutowicz zaczął w przymierzu z Albrechtem II i zakonem myśleć o wojnie z Polską właśnie w 1438 r. i dopiero 31 X 1439 r. odnowił poprzednie zapisy unijne, zresztą na wyraźne żądanie króla polskiego ${ }^{43}$.

W tym miejscu powstaje pytanie, czy rzeczywiście, jak chce tradycyjna literatura, Zbigniew Oleśnicki był zwolennikiem inkorporacji Litwy? Np. E. Maleczyńska uważała, że Zygmunt Kiejstutowicz był właściwie kreaturą Oleśnickiego, a po śmierci wielkiego księcia plan biskupa w sprawie litewskiej ograniczał się tylko do podziału i stopniowej inkorporacji Litwy, a także walki o patrimonium dla Michała, o inkorporację Drohiczyna do Mazowsza i później o przynależność Wołynia i Podola ${ }^{44}$. Ostatnio rozprawił się $z$ tymi poglądami J. Nikodem, dając po gruntownej analizie źródeł odpowiedź jednoznacznie negatywną, zwłaszcza w sprawie inkorporacji ${ }^{45}$. Wydaje się jednak, że serce Oleśnickiego rzeczywiście mogło bić przychylnie dla idei inkorporacji, (co możemy wywnioskować również na podstawie poglądów bliskiego mu Długosza) ${ }^{46}$, ale rozum polityczny zapewne mu mówił, że takie postępowanie jest niestety niemożliwe. Oczywiście, gdy Polacy wraz z Oleśnickim grozili Litwinom inkorporacją, robili to z wyrachowania politycznego, wiedząc, jak słusznie zauważa Nikodem, że jest to tylko szantaż obliczony na doraźne rezultaty polityczne. Niemniej gdyby układ sił był inny, z pewnością te pogróżki mogły być dla Litwy bardziej realne, a plan inkorporacji mógł zostać podda-

${ }^{41}$ AU, nr 63-64; Cod. ep., t. 1, s. 86-88; Annales, XI-XII, s. 175-176; M. Koczerska, Zbigniew Oleśnicki i Kościól krakowski w czasach jego pontyfikatu (1423-1455), Warszawa 2004, Aneks II, nr 9.

${ }^{42}$ Historia Dyplomacji polskiej, t. 1, red. M. Biskup, Warszawa 1980, s. 408; L. Kolankowski, Dzieje Wielkiego Księstwa Litewskiego, s. 212 n.

${ }^{43}$ Cod. ep., t.2, nr 261-262; A. Lewicki, Przymierze Zygmunta W. Ks. Litewskiego z królem rzymskim Albrechtem II, Rozprawy (Polskiej) Akademii Umiejętności, Wydział Historyczno-Filozoficzny, t. 37: 1898 , s. 297 n.

${ }^{44}$ E. Maleczyńska, Spoleczeństwo polskie, s. 156.

${ }^{45}$ J. Nikodem, Zbigniew Oleśnicki wobec unii polsko-litewskiej do śmierci Jagielly, „Nasza Przeszłość" t. 91:1999, s. 101-151; tegoż, Zbigniew Oleśnicki wobec unii polsko-litewskiej w latach 1434-1453, „Nasza Przeszlość" t. 92:1999, s. 85-135.

${ }^{46} \mathrm{Na}$ temat poglądów Jana Długosza dotyczących inkorporacji Litwy do Polski zob.: J. Krzyżaniakowa, Pojęcie państwa i narodu w „Rocznikach" Jana Dlugosza, [w:] Dlugossiana, cz.2, s. 77-78; M. Kosman, Polacy o Litwinach (do polowy XVI wieku), [w:] Spoleczeństwo Polski Średniowiecznej, t. 3, red. S. K. Kuczyński, Warszawa 1985, s. 403 n. 
ny próbie realizacji. W polityce wszak zazwyczaj nie ma sentymentów. W przypadku hipotetycznego powodzenia tych zamierzeń rodzi się jednak następujące pytanie: jak długo udałoby się Polakom utrzymać w jednym państwie wcielone przymusowo tak ogromne przestrzenie, $w$ dużej mierze obce jeszcze kulturowo i cywilizacyjnie w porównaniu do obszarów Korony?

Reasumując, fakty przez nas opisane przekonują, iż najważniejsi członkowie polskiego episkopatu wraz ze swoją tytularną głową, prymasem Wojciechem Jastrzębcem, czynnie zaangażowani się w spór koronacyjny. Dominującą rolę w tym sporze z pewnością odegrali przede wszystkim: biskup krakowski Zbigniew Oleśnicki i biskup włocławski Jan Szafraniec, będący zarazem kanclerzem Królestwa. Dążyli oni do załatwienia sporu po myśli polskiej racji stanu i aż do śmierci wielkiego księcia, sprzeciwiali się stanowczo jego planom koronacyjnym i znacznie wpływali tym samym na stanowisko Jagiełly. Podobnie było po $1430 \mathrm{r}$., w dobie powstania Świdrygiełły i rywalizacji o tron wielkoksiążęcy między bratem polskiego króla a Zygmuntem Kiejstutowiczem. W tych latach episkopat czynnie wspierał i uczestniczył w działaniach polskiej dyplomacji, dbając o to, aby nie dopuścić do niekorzystnego dla Korony przebiegu wydarzeń. 